\title{
Роль громадських організацій у ресоціалізації засуджених до позбавлення волі
}

\section{Проскура В.В., Львівська політехніка}

Виявлено, що, незважаючи на відсутність чіткого державного регулювання форм і напрямів діяльності громадських організацій (ГО), вони активно залучаються до діяльності установ виконання покарань (УВП) в різних сферах їх функціонування. Актуальність залучення ГО пов'язана 3 наступними чинниками: державні інституції не в змозі забезпечити успішну ресоціалізацію засуджених в контексті пенітенціарних закладів та створити передумови для подальшої іх реінтеграції у суспільство; працівники пенітенціарних установ та самі засуджені високо оцінюють діяльність ГО; представники ГО виступають важливим каналом зв'язку із соціумом, пропагуючи його норми та цінності тощо.

Встановлено, що роль ГО в ресоціалізації засуджених до позбавлення волі полягає у втіленні заходів, що безпосередньо сприяють повторному процесу засвоєння цими особами соціальних норм, цінностей, ролей та навичок, що є адаптивними для функціонування в некримінальних соціальних середовищах, а також сприяють активізації ресоціалізаційного впливу на засуджених з боку персоналу УВП.

3'ясовано, що основними функціями ГО щодо ресоціалізації засуджених до позбавлення волі є: 1) група функцій, що безпосередньо (або переважно) орієнтовані на засуджених (правова, психологічна, соціальна, матеріально-економічна, професійна, освітня, просвітницько-виховна, культурна, медична, фізкультурно-оздоровча), 2) група функцій, що не мають безпосередньої оріснтації на засуджених (інформування громадськості, налагодження співпраці, контролю, навчально-методичних заходів для працівників). Встановлено, що найширше у першій групі представлені професійна, просвітницько-виховна та культурна функції, а в другій - функція інформування громадськості.

3'ясовано, що за локалізацією серед ГО переважають місцеві та всеукраїнські, а за функціями - ГО з чітко вираженою соціальною спрямованістю, правозахисні та ті, які сприяють діяльності інших ГО.

Ключові слова: державна кримінально-виконавча служба; громадські організації; ре-соціалізація; засуджені до позбавлення волі; установа виконання покарань; функції

\section{The role of NGO's in resocialization of incarcerated individuals}

\section{Proskura V.V., Lviv polytechnic}

This article presents the results of theoretical and empirical analyses of the role of NGOs in penitentiary resocialization. We found the lack of clear state regulation of the forms and directions of NGO activity. Despite this, NGOs are actively involved in the activities in the penitentiary institutions in different spheres of their functioning. The urgency of NGOs involvement is related to the following factors: state institutions are not able to ensure successful re-socialization of convicts in the context of penitentiary institutions and create preconditions for their further reintegration into society; prison staff and prisoners themselves highly appreciate the activities of the NGO; NGOs represent an important channel of communication with society, promoting its norms and values; the members of the NGOs help to reduce the feeling of rejection and overcome the negative mental states of convicts; NGOs contribute to the establishment of a support system for convicts both during and after serving the sentence, etc.

It is established that the role of NGOs in the resocialization of incarcerated individuals to imprisonment consists of the implementation of measures that directly contribute to the repeated process of persons' assimilation of social norms, values, roles and skills that are adaptive for functioning in non-criminal social environments, and also contribute to the formation of re-socialization influence on convicts on the part of the personnel of the penitentiary institutions.

It is revealed that the main functions of the NGO in relation to the re-socialization of incarcerated persons are: 1) a group of functions that are directly (or mainly) oriented on convicts (legal, psychological, social, material and economic, professional, educational, bringing up, cultural, medical, physical culture), 2) a group of functions that do not directly target convicts (informing the public, establishing cooperation, monitoring, teaching and methodological measures for employees). It has been established that the broadest group in the first group is represented by professional, educational, educational and cultural functions, and in the second, the function of informing the public.

It was found out that the majority of NGOs are of local and all-nation localization, and according to the functions of the NGO with a clearly defined social orientation, human rights defenders and those that facilitate the activities of the other NGOs.

Keywords: state criminal-executive service; non-governmental organizations; re-socialization; incarcerated individuals; penitentiary institution; functions 


\title{
Роль общественных организаций в ресоциализации осужденных к лишению свободы
}

\author{
Проскура В.В., Львовская политехника
}

Выявлено, что, несмотря на отсутствие четкого государственного регулирования форм и направлений деятельности общественных организаций (ОО), они активно привлекаются к деятельности учреждений исполнения наказаний (УИН) в различных сферах их функционирования. Актуальность привлечения ОО связана со следующими факторами: государственные институты не в состоянии обеспечить успешную ресоциализации осужденных в контексте пенитенциарных учреждений и создать предпосылки для дальнейшей их реинтеграции в общество; работники пенитенциарных учреждений и сами осужденные высоко оценивают деятельность ОО; представители ОО выступают важным каналом связи с социумом, пропагандируя его нормы и ценности и т.д.

Установлено, что роль ГО в в ресоциализации осужденных к лишению свободы заключается в воплощении мероприятий, непосредственно способствующих повторному процессу усвоения этими лицами социальных норм, ценностей, ролей и навыков, являющихся адаптивными для функционирования в некриминальных социальных средах, а также способствуют активизации ресоциализационного влияния на осужденных со стороны персонала УВП.

Установлено, что основными функциями ОО в сфере ресоциализации осужденных к лишению свободы являются: 1) группа функций, непосредственно (или преимущественно) ориентированных на осужденных (правовая, психологическая, социальная, материально-экономическая, профессиональная, образовательная, просветительско-воспитательная, культурная, медицинская, физкультурно-оздоровительная), 2) группа функций, не имеют непосредственной ориентации на осужденных (информирование общественности, налаживание сотрудничества, контроля, учебно-методических мероприятий для работников). Установлено, что наиболее широко в первой группе представлены профессиональная, просветительско-воспитательная и культурная функции, а во второй - функция информирования общественности.

Установлено, что по локализации среди ОО преобладают местные и всеукраинские, а по функциям - ОО с четко выраженной социальной направленностью, правозащитные и те, которые способствуют деятельности других ГО.

Ключевые слова: государственная уголовно-исполнительная служба; общественные организации; ресоциализация; осужденные к лишению свободы; учреждение исполнения наказаний; функции

\section{Постановка проблеми.}

Уучасний етап існування українського соціуму характеризується високим рівнем злочинності і широким застосуванням позбавлення волі як засобу боротьби 3 нею. Масштаб цього явища підтверджується статистичними даними Державної кримінально-виконавчої служби (ДКВС): станом на 1 січня 2018 р. в установах виконання покарань та слідчих ізоляторах, розташованих на території, контрольованій українською владою, трималось 57100 осіб. Зокрема, у 113 кримінально-виконавчих установах утримувалося 39513 засуджених [8].

Діяльність, спрямована на виправлення, ресоціалізацію та підготовку засудженого до життя в суспільстві у контексті установи виконання покарань (УВП), суттєво ускладнюється тим, що умови відбування покарань кардинально відрізняються від умов існування індивіда у суспільстві, а чіткі критерії оцінювання діяльності УВП у цьому напрямі відсутні.

Суспільство мало би бути зацікавленим в успішній ресоціалізації засуджених, адже від успішності цього процесу залежить якість і без- печність життя решти членів суспільства. Так, протягом 2017 року з установ виконання покарань звільнилося 17681 особа (у 2016 році - 25085 осіб) [8]. Проте життєва ситуація конкретного індивіда, навіть якщо він щиро хоче порвати зі злочинною діяльністю, найчастіше мало хвилює як суспільство в цілому, так і окремих його членів.

У Кримінальному кодексі України зазначено, що одним із принципів виконання покарань $\epsilon$ участь у ньому громадськості, а громадський вплив $є$ засобом виправлення і ресоціалізації засуджених. Відтак, ресоціалізаційну роботу в установах виконання покарань може вдосконалити активніше залучення громадських організацій (ГО), які допомагають підтримувати зв'язок засудженого з суспільством, його нормами, цінностями; сприяють зменшенню відчуття засудженими відкинутості; надають матеріальну підтримку тощо. Така участь ГО має розглядатися не як додаткова допомога ДКВС, а як невід’ємна частина програм профілактики злочинності.

Аналіз останніх досліджень і публікацій.

Вивченням особливостей діяльності громадських організацій, їх типологізації були присвячені 
роботи вітчизняних науковців О. Бень, П. Дігтяр та ін.

Науково-прикладні аспекти ресоціалізації засуджених до позбавлення волі були досліджені у працях О. Богатирьової, Л. Жук, О. Караман, О. Неживець, А. Осипової, О. Романенко, О. Турчиної та ін. Однак, незважаючи на значний внесок у науку зазначених авторів, питання вивчення ролі ГО при роботі із засудженими до позбавлення волі в Україні залишаються недостатньо вивченими.

Мета статті: визначити роль та форми участі громадських організацій у роботі, спрямованій на ресоціалізацію засуджених до позбавлення волі.

Виклад основного матеріалу і результатів дослідження.

Громадські організації часто називають організаціями третього сектору, на відміну від першого (держава та пов'язані з нею інститути) та другого (комерційні інститути) секторів. На протиставленні громадських організацій державним виокремлюють недержавні організації (НДО) та їх синонім неурядові організації (НУО, англ. - NGO) - створювані і керовані громадянами без формального втручання держави. На протиставленні комерційному статусу громадських організацій засновані поняття: неприбуткові організації (НПО) - (термін поширений у США) та волонтерські організації (BО) (термін популярний у Великій Британіі). В українській науковій літературі та практиці найчастіше використовують термін «громадські організації», рідше - «громадські об'єднання» та «неурядові організації» [1, с. 339-340], також благодійні організації (БО). Розглянемо як ці організації працюють в напрямку ресоціалізації осіб, засуджених до позбавлення волі.

Факт потрапляння засудженого в УВП переважно $є$ свідченням неадекватності його попередньої соціалізації та потребі у ресоціалізації повторному процесі засвоєння соціальних норм, цінностей, ролей та навичок, що є адаптивними для функціонування в некримінальних соціальних середовищах. Ресоціалізація пов'язана 3 соціальним досвідом, розвитком індивіда під впливом суспільства та агентів соціалізації. Процес ресоціалізації залежить від створення умов для розвитку позитивних просоціальних рис, а сам засуджений має поступово ставати суб'єктом власної ресоціалізації.

Основними етапами процесу ресоціалізації $\epsilon$ пенітенціарний (під час відбування покарання) i постпенітенціарний (після звільнення засудженого від відбування покарання) [7, с.62]. В цій статті ми основну увагу зосередимо саме на пенітенціар- ному етапі у зв'язку з його значною тривалістю та важливістю у закладанні передумов успішності / неуспішності постпенітенціарної ресоціалізації.

Цей етап, на думку О. Караман, також поділяється на декілька під етапів / періодів: 1) адаптація до умов виконання покарання; 2) процес виправлення та самовиховання засуджених; 3) підготовка засуджених до звільнення [7, с. 62]. На кожному $з$ етапів та періодів важливим $є$ усунення або нейтралізація негативних факторів, які перешкоджають поверненню засуджених після відбуття покарання до суспільно корисної діяльності [5, с. 62].

Забезпечити в рамках УВП ресоціалізацію засуджених, яка би дозволяла їм у подальшому успішно реінтегруватися у суспільство $€$ складним завданням. Під час відбування покарання засуджений повністю або ж частково десоціалізується паралельно із «затуханням» відповідних зразків недевіантної соціальної поведінки. Загалом, відбування покарання у вигляді позбавлення волі характеризується наступними чинниками: 1) розрив соціально корисних зв'язків на фоні загальної ізоляції від суспільства; 2) перебування під впливом норм кримінальної субкультури; 3) підпорядкування жорстким нормам; 4) стигматизуючий характер самого факту соціальної ізоляції; 5) наявність психологічних проблем [9, с. 158159]; 6) формування залежності від інших у вирішенні власних проблем тощо.

Вітчизняне законодавство передбачає низку заходів, покликаних знівелювати негативний вплив відбування покарання (наприклад, спрямованих на збереження соціально корисних зв'язків засуджених та підготовки їх до звільнення з УВП), однак вони здебільшого $€$ малоефективними через формальність виконання і брак ресурсів.

Водночас засудженому під час перебування в УВП важливо знати, що про нього турбуються та вирішують проблеми, які він сам розв'язати не в змозі. Ефективна цілеспрямована діяльність персоналу УВП для забезпечення виправлення i peсоціалізації засуджених неможлива без залучення інших соціальних інституцій $[2$, с. 1] та агентів ресоціалізації.

На думку О. Турчиної, громадський вплив повинен відбуватися на усіх етапах, починаючи від затримання за вчинення злочину; після набрання обвинувальним вироком суду законної сили (найдовший процес взаємодії під час відбування покарання); після закінчення строку відбування покарання - завершальний етап закріплення та практичної реалізації напрацьованого досвіду [13, с.137]. 
До агентів пенітенціарного етапу ресоціалізації можна віднести державні структури (наприклад, відділи соціально-виховної та психологічної роботи УВП) та недержавні (наприклад, ГО та конкретні представники суспільства, що можуть 3 певною періодичністю взаємодіяти із засудженим). Родичі і близькі засуджених, представники ГО та ЗМІ також можуть відвідати УВП під час проведення в них Днів відкритих дверей.

Важливе місце в пенітенціарному етапі ресоціалізаційної роботи посідає підготовка засуджених до звільнення, яка передбачає надання комплексу правових, економічних, організаційних, психологічних, соціальних та інших заходів. Його суб'єктами виступають також організації, об'єднання громадян, а також фізичні особи, які беруть участь на добровільних засадах, а обсяг та форма участі визначаються їх установчими документами $[6$, ст. 1,23$]$. Однак у Наказі «Про затвердження Порядку взаємодії суб'єктів соціального патронажу звільнених осіб» у механізмі цієї взаємодії ГО безпосередньо не згадуються.

Незважаючи на розмитість державного регулювання форм і напрямів діяльності ГО, вони активно залучаються до діяльності УВП в різних сферах їх функціонування. За даними ДКВС, станом на кінець 2017 року з УВП у напрямку сприяння ресоціалізації засуджених співпрацювало 367 об'єднань громадян, 29 із яких - міжнародні неурядові благодійні організації, 106 організацій всеукраїнського, 107 - регіонального, та 125 - місцевого рівня. Представниками громадських організацій за 2017 рік здійснено 12,4 тис. відвідувань установ, проведено 11,4 тис. заходів, які охопили 41 тис. засуджених [10].

Розглянемо детальніше соціальні функції громадських організацій. Зіставивши їх зі сферами діяльності соціальних інститутів суспільства, О. Бень пропонує виділити соціальні, виховні, політичні, економічні, культурні [1, с. 343]. За функціями П. Дігтяр поділяє ГО України на декілька груп: 1) «взаємодопомоги»; 2) чітко соціальної спрямованості; 3) «клубного типу» для груп самовдосконалення; 4) «суспільно-охоронного» характеру; 5) правозахисні; 6) ті, що сприяють діяльності інших ГО [3, с. 194].

Працівники пенітенціарних установ також доволі високо оцінюють діяльність ГО. За результатами дослідження, проведеного автором статті, співпрацю із громадськими організаціями як ефективну оцінюють $41,9 \%$, в той час як неефективну $-17,6 \%$ респондентів [11, с. 117]. За даними О. Романенка, діяльність громадських організацій позитивно оцінюють ще більше працівників УВП - майже $73 \%$ вважають діяльність громадських організацій в цілому ефективною, а 95\% опитаних вважають їі необхідною складовою у сфері ресоціалізації засуджених [12, с. 14].

Важливим контекстом діяльності ГО в УВП $є$ те, що переважна більшість засуджених має позитивне ставлення до діяльності ГО. За результатами дослідження автора статті, 79,3\% засуджених знають про діяльність конкретних ГО щодо допомоги засудженим та звільненим із місць позбавлення волі, а 20,7\% вже отримують або планують отримувати від них допомогу [11, с. 115]. А зважаючи на обмеженість реальної ініціативи з боку засуджених, О. Богатирьова вважає, що саме громадські інституції повинні ініціювати взаємодію iз засудженими $[2$, с. 3$]$.

Проаналізуємо види діяльності, втілювані громадськими організаціями в УВП України. Основним методом дослідження ми обрали кількісний контент-аналіз тексту. Джерелами для аналізу виступали он-лайнові новини, розміщені на веб-сайті Державної кримінально-виконавчої служби України. Це найбільше відкрите джерело, яке систематизує і поширює інформацію в сфері виконання покарань.

Критеріями, за якими аналізувалися обрані джерела були:

1) наявність у публікації інформації про діяльність ГО та / або окремих їх представників щодо осіб, які відбували покарання у вітчизняних УВП;

2) дата розміщення після 1 січня 2017 року.

Вибіркова сукупність $є$ еквівалентною генеральній у зв'язку з обмеженістю кількості інформації по заданій темі. Одиницями аналізу виступали окремі слова, словосполучення, що відображали вище згадувані види діяльності. Одиницею підрахунку була кількість згадувань одиниць аналізу. Усього проаналізовано 71 публікація - 61 у 2017 році та 10 у 2018 році.

О. Романенко виділяе такі напрямки діяльності ГО в роботі пенітенціарних установ: а) участь у соціально-виховній роботі; б) сприяння матеріально-технічному забезпеченню пенітенціарної діяльності; в) освіта засуджених; г) громадський контроль; д) надання допомоги персоналу установ виконання покарань [12, с. 15].

У рамках вивчення процесу підготовки засуджених до життя у суспільстві нами було встановлено, що відповідна робота може здійснюватися у наступних основних напрямках (i відповідних функціях): 1) правовий, 2) психологічний, 3) соціальний, 4) матеріально-економіч- 
ний, 5) професійний, 6) освітній, 7) медичний, 8) фізкультурно-оздоровчий тощо. Взявши частково за основу цю класифікацію, ми емпірично виділили 14 функцій ГО. Їх можна умовно поділити на дві великі групи функцій: 1) ті, що безпосередньо (або переважно) орієнтовані на засуджених та 2) ті, що не мають безпосередньої орієнтації на засуджених. Усього нами було виокремлено 65 видів діяльності громадських організацій (Див. табл. 1).

Табличя 1.

Спектральний розподіл видів діяльності ГО у пенітенціарних установах відповідно до їх функцій

\begin{tabular}{|c|c|c|}
\hline $\begin{array}{l}\text { № } \\
3 / \Pi\end{array}$ & Функції & Види діяльності \\
\hline 1 & правова & $\begin{array}{l}\text { 1) участь у засіданні робочої групи Комітету Верховної } \\
\text { Ради України з питань законодавчого забезпечення, } \\
\text { правоохоронної діяльності та Міністерства юстиції України } \\
\text { 2) участь в обговоренні законопроектів, } \\
\text { 3) проведення правових лекцій (напр., «Права людини при } \\
\text { взаємодії з поліцією»), (3) } \\
\text { 4) надання індивідуальних правових консультацій, } \\
\text { 5) інформування про можливість отримання допомоги у } \\
\text { громадських об’єднань }\end{array}$ \\
\hline 2 & психологічна & 1) розвиток психологічних навичок засуджених \\
\hline 3 & соціальна & $\begin{array}{l}\text { 1) інформування про вихід випусків телепроектів про життя } \\
\text { і виправлення засуджених (2), } \\
\text { 2) організація відвідувань громадські діячами, науковцями } \\
\text { та журналістами, } \\
\text { 4) організація вистав, } \\
\text { 3) презентація послуг Центру, що допомагає особам, які } \\
\text { повертаються } 3 \text { місць позбавлення волі, } \\
\text { 5) проведення занять про вирішення соціально-побутових } \\
\text { питань після звільнення, } \\
\text { 6) спілкування представників ГО та громадськості із } \\
\text { засудженими, } \\
\text { 7) проведення тематичних виховних та інформаційних } \\
\text { годин для засуджених }\end{array}$ \\
\hline 4 & $\begin{array}{l}\text { матеріально- } \\
\text { економічна }\end{array}$ & $\begin{array}{l}\text { 1) надання засудженим гуманітарної допомоги для } \\
\text { індивідуального споживання (продукти харчування, засоби } \\
\text { особистої гігієни), (3) } \\
\text { 2) надання засудженим гуманітарної допомоги святково- } \\
\text { ритуального характеру (великодні паска та крашанка), } \\
\text { 3) надання подарунків переможцям змагань та конкурсів, }\end{array}$ \\
\hline
\end{tabular}




\begin{tabular}{|c|c|c|}
\hline & & $\begin{array}{l}\text { 4) надання гуманітарної допомоги у вигляді крісла для } \\
\text { людини з інвалідністю, } \\
\text { 5) надання перукарських послуг, } \\
\text { 6) надання гуманітарної допомоги для потреб } \\
\text { функціонування УВП (пральна машина) }\end{array}$ \\
\hline 5 & професійна & $\begin{array}{l}\text { 1) офіційне працевлаштування засудженого для надання } \\
\text { послуг іншим засудженим } \\
\text { 2) проведення професійних курсів (напр., за напрямами } \\
\text { «Кухар-кондитер», «Юний фотограф»), } \\
\text { 3) проведення біснес-курсів, } \\
\text { 4) проведення конкурсів серед засуджених (напр., змагання } \\
\text { бізнес-планів), } \\
\text { 5) видавання сертифікатів, } \\
\text { 6) проведення профорієнтаційних занять, } \\
\text { 7) проведення мотиваційних занять, } \\
\text { 8) демонстрація тематичних фільмів, } \\
\text { 9) залучення засуджених до обробки земельних ділянок та } \\
\text { висаджування рослин в рамках навчання на курсах }\end{array}$ \\
\hline 6 & освітня & $\begin{array}{l}\text { 1) організація дистанційного вивчення англійської мови, } \\
\text { 2) проведення майстер-класів та практичних занять (напр., } \\
\text { перукарських) (2) }\end{array}$ \\
\hline 7 & $\begin{array}{l}\text { просвітницько- } \\
\text { виховні }\end{array}$ & $\begin{array}{l}\text { 1) проведення тренінгів (напр., «Репродуктивне здоров’я і } \\
\text { планування сім’ї», розв’язання конфліктів, профілактика } \\
\text { інфікування ВІЛ (7) } \\
\text { 2) проведення просвітницько-профілактичних занять } \\
\text { (напр., «Моральні принципи життя»), (2) } \\
\text { 3) проведення консультацій (напр., пошуку себе у } \\
\text { суспільстві після відбуття покарання), } \\
\text { 4) проведення лекцій національно-патріотичного характеру } \\
\text { (напр., «Історія української писемності та мови», «100- } \\
\text { річчя Української революції» (2) } \\
\text { 5) перегляд тематичних кінофільмів (2) } \\
\text { 6) проведення заходів/акцій (напр., до Дня Пам’яті } \\
\text { померлих від СНІДу, до Дня довкілля), (2) } \\
\text { 7) видавання сертифікатів, }\end{array}$ \\
\hline
\end{tabular}




\begin{tabular}{|c|c|c|}
\hline & & $\begin{array}{l}\text { 8) анкетування засуджених (напр., щодо обізнаності про } \\
\text { причини захворювання на ВІЛ/СНІД) (2) }\end{array}$ \\
\hline 8 & культурна & $\begin{array}{l}\text { 1) організація концертів для засуджених (напр., з нагоди } \\
\text { відзначення Дня захисника України, «Пісні та вірші, } \\
\text { народжені в АТО») (8) } \\
\text { 2) проведення творчих конкурсів (напр., на фестивалі «Арт } \\
\text { Примирення»), } \\
\text { 3) організація зустрічей з представниками громадських } \\
\text { організацій, } \\
\text { 4) проведення виховних зустрічей із засудженими } \\
\text { 5) відкриття пам`ятників (напр., «Загиблим мешканцям м. } \\
\text { Мар`їнка та воїнам АТО») } \\
\text { 6) перегляд тематичних кінофільмів, } \\
\text { 7) проведення екскурсії вихованцям до історичних } \\
\text { видатних пам’яток міста, } \\
\text { 8) організація свят (Маланки) }\end{array}$ \\
\hline 9 & медична & $\begin{array}{l}\text { 1) надання гуманітарної допомоги у виді обладнання для } \\
\text { лікарень, } \\
\text { 2) надання гуманітарної допомоги у виді витратних } \\
\text { матеріалів для діагностики та лікування туберкульозу (4) }\end{array}$ \\
\hline 10 & $\begin{array}{l}\text { фізкультурно- } \\
\text { оздоровча }\end{array}$ & 1) наявність спортзалу в УВП \\
\hline 11 & $\begin{array}{l}\text { інформування } \\
\text { громадськості }\end{array}$ & $\begin{array}{l}\text { 1) проведення «Днів відкритих дверей» та «Днів } \\
\text { відділення» (9), } \\
\text { 2) проведення відкритих заходів (напр., «Свято останнього } \\
\text { дзвоника», інспектування працевлаштування засуджених, } \\
\text { подання засудженого до умовно-дострокового звільнення) } \\
\text { (3), } \\
\text { 3) презентація планів проведення заходів для засуджених } \\
\text { (3), } \\
\text { 4) підведення підсумків з питань ресоціалізації засуджених, } \\
\text { 5) підведення підсумків з питань з висвітлення у ЗМІ } \\
\text { діяльності ДкВС, } \\
\text { 6) проведення науково-практичних онлайн-конференцій } \\
\text { (напр., на тему “Педагогічна спадщина А.С. Макаренка в }\end{array}$ \\
\hline
\end{tabular}




\begin{tabular}{|c|c|c|}
\hline & & $\begin{array}{l}\text { науці та практиці”), } \\
\text { ознайомлення присутніх з умовами проживання, } \\
\text { харчування, навчання та відпочинку засуджених, } \\
\text { 7) оформлення Книги відгуків, } \\
\text { 8) проведення зустрічей родичів засуджених з начальником } \\
\text { установи або його заступником }\end{array}$ \\
\hline \multirow[t]{3}{*}{12} & $\begin{array}{l}\text { налагодження } \\
\text { співпраці }\end{array}$ & $\begin{array}{l}\text { 1) укладення угоди УВП з ГО, } \\
\text { 2) залучення фахівців ГО до роботи з засудженими (напр., } \\
\text { секції авіаконструкторів «Юний авіаконструктор»), } \\
\text { 3) узгодження залучення вихованців УВП до оплачуваних } \\
\text { робіт (з благоустрою міста на базі Центру надання } \\
\text { адміністративних послуг) }\end{array}$ \\
\hline & контролю & $\begin{array}{l}\text { 1) перевірка діяльності організації інших ГО (напр., ГО } \\
\text { «Клуб «Шанс») }\end{array}$ \\
\hline & $\begin{array}{l}\text { навчально- } \\
\text { методичних } \\
\text { заходів для } \\
\text { працівників }\end{array}$ & $\begin{array}{l}\text { 1) проведення міжнародних практичних семінарів (напр., } \\
\text { «Методи реабілітації в виховних колоніях для } \\
\text { неповнолітніх»), } \\
\text { 2) видавання сертифікатів, } \\
\text { 3) проведення інформаційних занять для персоналу УВП } \\
\text { (напр., по зниженню рівня стигми та дискримінації } \\
\text { представників уразливих груп та людей, які живуть з ВІЛ в } \\
\text { УВП). }\end{array}$ \\
\hline
\end{tabular}

Найширше у групі функцій, що безпосередньо (або переважно) орієнтовані на засуджених, представлена професійна функція - дев'ять видів діяльності. За нею йде просвітницько-виховна функція - вісім видів діяльності, серед яких переважають тренінги, спрямовані на надання i інформації та формування навичок у різних сферах соціального життя. Вісім видів діяльності має також культурна функція, в якій явно переважає організація концертів для засуджених. Соціальна функція представлена сімома видами діяльності. Розглянемо цю групу функцій докладніше.

Правова функиія реалізовувалася на мікрорівні у вигляді надання засудженим індивідуальних та групових консультацій, а на макрорівні - участі ГО в лобіюванні законопроектів. Наприклад, ГО «Пенітенціарна асоціація України» та «Союз «Золотий Вік України» брали участь в обговоренні законопроектів про Дисциплінарний статут пенітенціарної системи та «Про правовий статус засуджених, які відбували покарання на тимчасово окупованій території...».

Психологічна функиія може полягати у проведенні індивідуальних консультацій психолога, застосуванні психодіагностики, тренінгів із метою психологічної корекції або психологічної реабілітації особистості тощо. На сайті вона представлена лише епізодично. Зокрема, один із напрямків тренінгу «Будуємо майбутнє разом», втілюваних Всеукраїнським громадським центром «Волонтер», спрямований на розвиток психологічних навичок засуджених.

Соціальна функція, на нашу думку, найбільш безпосередньо пов'язана зі створенням умов для ресоціалізації засуджених та реінтеграцією їх у соціум. Вона втілюється у вигляді сприяння за- 
судженим у їх ресоціалізації. Зокрема, згадується презентація у «Надержинщинській виправній колонії (№ 65)» послуг Центру соціальної адаптації звільнених осіб «Дім на півдороги», що допомагає жінкам, які повертаються 3 місць позбавлення волі. Представники державних установ також інформують про діяльність ГО, що діють у цій cфеpi.

Інший напрямок соціальної функції полягає у формуванні більш позитивного соціального сприйняття осіб, які відбували покарання у вигляді позбавлення волі та подоланні негативних стереотипів щодо цих осіб. Наприклад, в одній із публікацій наявна інформація про вихід чергового випуску проекту «Розмови на межі», у яких засуджені розповідають власні життєві історії з метою донесення до суспільства думки про можливість позитивних особистісних змін у цих людей. Також може полягати у посиленні взаємодії засуджених із представниками суспільства.

Матеріально-економічна функиія згадується у контексті надання гуманітарної допомоги засудженим у вигляді продуктів харчування та засобів особистої гігієни, отриманні засудженими великодніх пасок та крашанок тощо. Матеріальні заохочення (подарунки) могли надаватися в якості винагороди за успішну участь засуджених у навчанні на курсах, котрі організовували ГО. Також, гуманітарна допомога надавалася для покращення побуту засуджених - наприклад, у вигляді пральної машини, наданої Приазовській виправній колонії.

Професійна функиія полягає у сприянні отриманню спеціальності та їх працевлаштуванню. Найчастіше втілюється у вигляді проведення курсів, що допоможуть знайти роботу як у якості найманого працівника, так і самозайнятого. У цьому контексті згадуються лише дві установи: Кременчуцька та Мелітопольська виховні колонії. Наявна інформація про оформлення засудженого на посаду соціального працівника у ВІЛ-сервісній організації для надання комплексних послуг іншим засудженим за принципом «рівний-рівному» у Сумській виправній колонії.

Освітня функиія, відповідно до згадувань, реалізується у одній виховній колонії, де перебувають особи жіночої статі віком до 18 років. Наприклад, дистанційний курс навчання англійської мови, майстер клас «Стиль та краса» та бесіди щодо професії перукаря тощо.

Просвітницько-виховна представлена доволі широким спектром за тематикою та видами діяльності. Наприклад, Полтавський обласний благодійний фонд (БФ) «Громадське здоров'я» у Кременчуцькій виховній колонії проводив інтерактивні профілактично-розвивальні ігри з метою попередження соціально-негативних явищ, мінітренінг «Твоє життя - твій вибір», профілактичні заняття «Репродуктивне здоров'я» тощо.

Культурна функиія представлена широко як у кількісному, так і якісному вимірах. Найчастіше це організація концертів (наприклад, із нагоди відзначення Дня захисника України), творчі конкурси, перегляди тематичних фільмів.

Медична функція передбачає збереження здоров'я шляхом певних профілактичних та лікувальних заходів. Згадується в контексті надання Покровській виправній колонії (спеціалізована туберкульозна лікарня) обладнання, витратних матеріалів для діагностики туберкульозної інфекції та протитуберкульозних препаратів.

Фізкультурно-оздоровча функція практично не була представлена за 2017-18 роки, лише $€$ згадка про наявність у Дніпропетровській установі виконання покарань (№ 4) спортзалу, який сприяс дітям у фізичному розвитку. В попередні періоди ця функція найчастіше реалізується у вигляді товариських матчів із футболу.

Найширше серед групи функцій, що не мають безпосередньої орієнтації на засуджених, представлена функиія інформування громадськості (дев'ять видів діяльності), в якій, у свою чергу, переважають проведення «Днів відкритих дверей». За три квартали 2017 року в УВП проведено 203 такі заходи, до яких було залучено 13828 засуджених, 2577 їх родичів, 369 представників громадськості [4]. Варто зазначити, що на фотозвітах, представлених у публікаціях, переважно присутня невелика кількість людей. Також може реалізовуватися і в інших формах - як міжнародна науково-практична онлайн-конференція на тему «Педагогічна спадщина А. С. Макаренка в науці та практиці» або підведення підсумків діяльності в напрямку ресоціалізації засуджених за певний період.

Функиія налагодження співпрайі стосується взаємодії з іншими соціальними інституціями в напрямку роботи із засудженими. Переважно згадується укладення угоди між конкретними УВП та ГО.

Функиія контролю здійснювалася з боку центральних органів ГО по відношенню до ГО, які діяли в окремих УВП. Так, у «Роменській виправній колонії» (№ 56) з боку центрального офісу Всеукраїнської БО «Всеукраїнська мережа людей, що живуть з ВІЛ / СНІД» проводила моніторингову 
перевірку діяльності ГО «Клуб «Шанс» та надала свої рекомендації. Контроль діяльності персоналу УВП міг згадуватися лише у зв'язку з залученням окремих представників ГО до участі у спостережних комісіях.

В рамках функиії навчально-методичних заходів для прачівників ГО проводять навчання, підвищення кваліфікації, видавання сертифікатів, залучаються до проведення міжнародних семінарів тощо. Як приклад можна навести семінар-тренінг Всеукраїнського громадського центру «Волонтер» для працівників УВП Південно-Східного міжрегіонального управління 3 питань виконання кримінальних покарань та пробації.

Доцільно розглянути й інші аспекти залучення ГО до ресоціалізації засуджених. Зокрема, за ознакою статусу / локалізації, переважно, це місцеві або всеукраїнські. Рідше іноземні (наприклад, волонтери Канадської пенітенціарної організації «Тюремне служіння») або міжнародні ГО (Міжнародний БФ «Альянс громадського здоров'я»). Частота згадування окремих ГО на сайті ДКВС: Полтавський обласний БФ «Громадське здоров'я» - сім разів, ГО «Союз «Золотий Вік України», Всеукраїнський громадський центр «Волонтер» та Всеукраїнська ГО «Кримінон-Надія» - по чотири рази. При описі окремих заходів згадується не лише безпосередній виконавець заходів, а й інституція, яка надала кошти чи в якийсь інший спосіб підтримала цей вид діяльності. Наприклад, проведення інформаційного заняття за підтримки Агентства США 3 Міжнародного розвитку (USAID).

Частина ГО мають вузький спектр допомоги наприклад, Міжнародний БФ «Альянс громадського здоров'я», - який надає гуманітарну допомогу у виді обладнання та різноманітних витратних матеріалів для діагностики туберкульозу, частина згадується у контексті втілення різноманітних заходів - ГО «Союз «Золотий Вік України».

Щодо видів діяльності, то найчастіше згадуються ті, що пов'язані з проведенням «Днів відкритих дверей» у рамках функції інформування громадськості - дев'ять разів; організацією концертів для засуджених у межах культурної функції - вісім разів; проведення тренінгів у рамках просвітницько-виховної функції - сім разів; надання гуманітарної допомоги у виді витратних матеріалів для діагностики та лікування туберкульозу в межах медичної функції - чотири рази. Видавання сертифікатів зустрічається одразу у трьох функціях і пов'язане саме з утіленням відповідних функцій. Часто заходи, що згадувалися в одній публікації, відносилися одразу до декількох видів діяльності та функцій: наприклад, підписання угоди і видання гуманітарної допомоги засудженим.

Інтенсивність проведення відображених заходів також відрізнялася. Зокрема, два просвітницьких заходи проводилися двома різними ГО - Всеукраїнською ГО «Кримінон-Надія» та Полтавським обласним БФ «Громадське здоров'я» в два дні поспіль. 3 іншого боку, наявні перерви у розміщенні публікацій. Наприклад, у 2017 р. 3 29 травня по 19 серпня не було жодної діяльності, в якій були би згадані ГО.

\section{Висновки.}

Вітчизняне законодавство дещо розмито окреслює форми і напрями діяльності ГО в пенітенціарній сфері. Необхідність залучення ГО актуалізується у зв'язку з тим, що державні інституції не в змозі забезпечити в контексті пенітенціарних закладів успішну ресоціалізацію засуджених та створити передумови для подальшої реінтеграції у суспільство. Основними аргументами на користь залучення ГО при роботі із засудженими до позбавлення волі належать: висока оцінка діяльності ГО як працівниками пенітенціарних установ, так і самими засудженими, здатність представників ГО бути каналом зв'язку із соціумом, пропагувати його норми та цінності; сприяти зменшенню відчуття відкинутості та подоланню негативних психічних станів засуджених; сприяти створенню системи підтримки засуджених як під час, так i після відбування покарання тощо.

Роль ГО в у ресоціалізації засуджених до позбавлення волі полягає у втіленні заходів, що безпосередньо сприяють повторному процесу засвоєння ними соціальних норм, цінностей, ролей та навичок, що $є$ адаптивними для функціонування в некримінальних соціальних середовищах, а також сприяють формуванню ефективнішого впливу на засуджених із боку персоналу УВП. Вона може бути опосередкованою, коли ГО (частіше міжнародні), не безпосередньо втілюють заходи, а лише надають певні види підтримки, зокрема фінансову.

Основними функціями ГО щодо ресоціалізації засуджених до позбавлення волі є: 1) група функцій, що безпосередньо (або переважно) орієнтовані на засуджених (правова, психологічна, соціальна, матеріально-економічна, професійна, освітня, просвітницько-виховна, культурна, медична, фізкультурно-оздоровча), 2) група функцій, що не мають безпосередньої орієнтації на засуджених (інформування громадськості, налагоджен- 
ня співпраці, контролю, навчально-методичних заходів для працівників). Найширше у першій групі представлені професійна, просвітницько-виховна та культурна функції, а у другій - функція інформування громадськості.

За локалізацією серед ГО переважають місцеві та всеукраїнські, а за функціями - ГО з чітко вираженою соціальною спрямованістю, правозахисні та ті, які сприяють діяльності інших ГО. Представлене дослідження являє собою наукову розвідку, на основі якої можна дослідити змістове наповнення та інтенсивність реалізації громадськими організаціями функцій у пенітенціарних закладах

\section{БІБІЛІОГРАФІЧНІ ПОСИЛАННЯ}

1. Бень О. Т. Молодіжні громадські організації: концептуалізація поняття, функції, класифікація / О. Т. Бень // Вісник Львівського університету. Серія соціологічна. - 2008. -№ 2. - С. 338-345.

2. Богатирьова О. І. Участь громадськості у процесі виправлення та ресоціалізації засуджених, підоблікових кримінально-виконавчій інспекції / О. І. Богатирьова // Правничий часопис Донецького університету. - 2013. - № 2. - С. 129-135. 3. Дігтяр П. А. Громадські організації в суспільно-політичній системі сучасної України: стан і перспективи розвитку / П. А. Дігтяр // Сторінки історії: збірник наук. праць. - Вип. 31. - Київ: ІВЦ Вид-во «Політехніка». - 2010. - С. $190-204$. 4. Дні відкритих дверей в установах виконання покарань / Державна служба статистики України. Режим доступу: http:// www.kvs.gov.ua/peniten/control/main/uk/publish/article/878628

5. Жук Л. А. Теоретичні засади соціальної та трудової ресоціалізації засуджених та осіб звільнених з місць позбавлення / Л. А. Жук, О. М. Неживець // Юридичний вісник. Повітряне і космічне право. - 2009. - № 3. - С. 59-64.

6. Про соціальну адаптацію осіб, які відбувають чи відбули покарання у виді обмеження волі або позбавлення волі на певний строк: закон України (Відомості Верховної Ради України (ВВР), 2011, № 38, ст. 380). Режим доступу: httр:// zakon3.rada.gov.ua/laws/show/3160-17

7. Караман О. Л. Досвід організації соціально-виховної роботи з неповнолітніми засудженими в спеціальній виховній установі / О. Л. Караман // Соціальна педагогіка: теорія та практика. - 2013. - № 2. - С. 53-60.

8. Кримінально-виконавча система України в 2017 році. Статистичний огляд // Громадська правозахисна організація «Донецький Меморіал». Режим доступу: http://ukrprison.org.ua/articles/1520330768

9. Осипова А. А. Справочник психолога по работе в кризисных ситуаціях / А. А. Осипова. - Ростов-на-Дону: Феникс, 2006. -315 c.

10. Підведення підсумків службової діяльності з питань ресоціалізації засуджених у 2017 році // Державна кримінально-виконавча служба України. Режим доступа: http://www.kvs.gov.ua/peniten/control/main/uk/publish/article/882796

11. Проскура В. В. Інституційне забезпечення процедур соціально-адаптаційної роботи з особами, які звільняються 3 місць позбавлення волі / В. В. Проскура // Социальные технологии: актуальные проблемы теории и практики. - 2007. - № 35. - С. 109-119.

12. Романенко О. В. Пенітенціарна функція демократичної правової держави та роль громадянського суспільства в механізми ії реалізації: автореф. дис. на здобуття наук. ступеня канд. юрид. наук: 12.00 .08 «Кримінальне право та кримінологія; кримінально-виконавче право» / О. В. Романенко. - Київ, 2004. - 19 с.

13. Турчина О. С. Роль громадського впливу в запобіганні вчиненню постпенітенціарних рецидивів / О. С. Турчина // Підприємництво, господарство і право. - 2017. - № 7. - С. 134-137.

\section{REFERENCES}

1. Ben, O.T. (2008). Molodizhni hromadski orhanizatsii: kontseptualizatsiia poniattia, funktsii, klasyfikatsiia [Youth civic organizations: conceptualization of the concept, functions, classification]. Visnyk Lvivskoho universytetu. Seriia sotsiolohichna, 2, 338-345 [in Ukrainian].

2. Bohatyrova, O.I. (2013). Uchast hromadskosti u protsesi vypravlennia ta resotsializatsii zasudzhenykh, pidoblikovykh kryminalno-vykonavchii inspektsii [Participation of the public in the process of correction and re-socialization of convicts, sub-criminally-executed inspection]. Pravnychyi chasopys Donetskoho universytetu, 2, 129-135 [in Ukrainian].

3. Dihtiar, P.A. (2010). Hromadski orhanizatsii v suspilno-politychnii systemi suchasnoi Ukrainy: stan i perspektyvy rozvytku [Public organizations in the socio-political system of modern Ukraine: the state and prospects of development]. Storinky istorii: zbirnyk nauk. prats - Pages of history: collection of sciences works, 31, 190-204. Kyiv: IVTs Vyd-vo «Politekhnika».

4. Dni vidkrytykh dverei v ustanovakh vykonannia pokaran [Open doors in penitentiary institutions]. Derzhavna sluzhba statystyky Ukrainy - State Statistics Service of Ukraine. Retrieved from: http://www.kvs.gov.ua/peniten/control/main/uk/ publish/article/878628 [in Ukrainian].

5. Zhuk, L.A., \& Nezhyvets, O.M. (2009). Teoretychni zasady sotsialnoi ta trudovoi resotsializatsii zasudzhenykh ta osib zvilnenykh z mists pozbavlennia [Theoretical principles of social and labor re-socialization of convicts and persons released from places of deprivation]. Yurydychnyi visnyk. Povitriane i kosmichne pravo, 3, 59-64 [in Ukrainian]. 
6. Pro sotsialnu adaptatsiiu osib, yaki vidbuvaiut chy vidbuly pokarannia u vydi obmezhennia voli abo pozbavlennia voli na pevnyi strok: zakon Ukrainy (Vidomosti Verkhovnoi Rady Ukrainy (VVR), 2011, № 38, st. 380) [On social adaptation of persons serving or sentenced in the form of restraint of liberty or imprisonment for a certain period: the Law of Ukraine (Bulletin of the Verkhovna Rada of Ukraine (VVR), 2011, № 38, Article 380)]. Retrieved from: http://zakon3.rada.gov.ua/ laws/show/3160-17 [in Ukrainian].

7. Karaman, O.L. (2013). Dosvid orhanizatsii sotsialno-vykhovnoi roboty z nepovnolitnimy zasudzhenymy v spetsialnii vykhovnii ustanovi [Experience in the organization of social work with juvenile convicts in a special educational institution]. Sotsialna pedahohika: teoriia ta praktyka, 2, 53-60 [in Ukrainian].

8. Kryminalno-vykonavcha systema Ukrainy v 2017 rotsi. Statystychnyi ohliad [The Criminal Execution System of Ukraine in 2017. Statistical Review]. Hromadska pravozakhysna orhanizatsiia «Donetskyi Memorial» - The Public Memorial Organization «Donetsk Memorial». Retrieved from: http://ukrprison.org.ua/articles/1520330768 [in Ukrainian].

9. Osypova, A.A. (2006). Spravochnyk psykholoha po rabote v kryzysnblkh sytuatsiiakh [A psychologist's manual on work in crisis situations]. Rostov-na-Donu: Fenyks [in Russian].

10. Pidvedennia pidsumkiv sluzhbovoi diialnosti z pytan resotsializatsii zasudzhenykh u 2017 rotsi [Summing up the official activities on the resocialization of convicts in 2017]. Derzhavna kryminalno-vykonavcha sluzhba Ukrainy State Criminal Execution Service of Ukraine. Retrieved from: http://www.kvs.gov.ua/peniten/control/main/uk/publish/ article/882796 [in Ukrainian].

11. Proskura, V.V. (2007). Instytutsiine zabezpechennia protsedur sotsialno-adaptatsiinoi roboty z osobamy, yaki zvilniaiutsia $\mathrm{z}$ mists pozbavlennia voli [Institutional provision of procedures for social adaptation work with persons released from places of deprivation of liberty]. Sotsyalnye tekhnolohii: aktualnye problemy teorii i praktiki, 35, 109-119 [in Ukrainian].

12. Romanenko, O.V. (2004). Penitentsiarna funktsiia demokratychnoi pravovoi derzhavy ta rol hromadianskoho suspilstva $v$ mekhanizmy yii realizatsii [Penitentiary function of a democratic legal state and the role of civil society in the mechanisms of its implementation]. Extended abstract of candidate's thesis. Kyiv [in Ukrainian].

13. Turchyna, O.S. (2017). Rol hromadskoho vplyvu v zapobihanni vchynenniu postpenitentsiarnykh retsydyviv [The role of public influence in preventing the post-penitentiary relapse]. Pidpryiemnytstvo, hospodarstvo i pravo, 7, 134-137 [in Ukrainian].

\section{Проскура Володимир Вячеславович}

Кандидат соціологічних наук, доцент, кафедра соціології та соціальної роботи

Львівська політехніка

79013 м. Львів, вул. Коновальця, 4

\section{Proskura Volodymyr}

$\mathrm{PhD}$ in sociology, Associate professor, sociology and social work department

Lviv polytechnic

4, Konovaltsya Str., Lviv, 79013, Ukraine

Email: proskura.v@gmail.com

Цитування: Проскура В. В. Роль громадських організацій у ресоціалізації засуджених до позбавлення волі / В. В. Проскура // Науково-теоретичний альманах «Грані». - 2018. - Т. 21. - № 5. - С. 54-65.

Citation: Proskura, V.V. (2018). Rol hromadskykh orhanizatsii u resotsializatsii zasudzhenykh do pozbavlennia voli [The role of NGO's in resocialization of incarcerated individuals]. Scientific and theoretical almanac «Grani», 21(5), 54-65. 